\title{
Association of interleukin-6 (-174 G/C) polymorphism with the prostate cancer risk: A meta-analysis
}

\author{
MINGYUAN YANG ${ }^{*}, \mathrm{CHAO}^{*}{ }^{*}$ and MING LI \\ Department of Orthopedics, Changhai Hospital, Second Military Medical University, Shanghai 200438, P.R. China
}

Received May 10, 2014; Accepted June 2, 2014

DOI: $10.3892 /$ br. 2014.300

\begin{abstract}
The aim of the present study was to determine whether the interleukin-6 (IL-6) (-174 G/C) gene polymorphism correlates with prostate cancer. A meta-analysis based on former studies was conducted and the results suggest that there was no significant association between IL-6 (-174 G/C) polymorphism and the prostate cancer risk. However, a recent study published in January 2014 showed that the GG genotype may be associated with an increased risk of prostate cancer in Caucasian subjects, whereas the CC genotype was associated with an increased risk in the African-American subjects, which was inconsistent with former studies. Databases, including PubMed, Embase, Web of Science, the Cochrane Library, Chinese Biomedical Literature Database and Wanfang database, were searched between January 1994 and March 2014 to determine the eligible IL-6 (-174 G/C) polymorphism studies and the susceptibility of the prostate cancer risk. A total of 11 studies with 10,745 cases and 13,473 controls fulfilled the inclusion criteria subsequent to assessment by two investigators. The pooled odds ratio (OR) with $95 \%$ confidence interval (95\% CI) was calculated to examine the associations, and subgroup analyses were performed according to the ethnicity. Overall, no significant association was found between the IL-6 (-174 G/C) polymorphism and prostate cancer risk, whereas the subgroup analysis suggested that the association between the IL-6 (-174 G/C) polymorphism and prostate cancer was slightly significant under the homozygote (CC vs. GG: OR, 3.43; 95\% CI, 1.01-11.71; $\mathrm{P}=0.049)$ and recessive models (CC vs. GG/GC: OR, 3.51; 95\% CI, 1.04-11.82; P=0.042) in African-American patients. However, no significant association was found in the Caucasian, Asian or mixed populations under the five genetic models by stratifying studies for ethnicity. In conclusion, the present study suggested that there
\end{abstract}

Correspondence to: Mr. Ming Li, Department of Orthopedics, Changhai Hospital, Second Military Medical University, 168 Changhai Road, Shanghai 200438, P.R. China

E-mail: liming0330@gmail.com

"Contributed equally

Key words: prostate cancer, interleukin-6, polymorphism, meta-analysis was no significant association between the IL-6 (-174 G/C) polymorphism and prostate cancer risk in Caucasian and Asian patients, whereas the CC genotype may be associated with an increased risk in the African-American patients.

\section{Introduction}

Prostate cancer is the most common type of cancer diagnosis in males and the estimated new prostate cancer cases and mortalities in 2013 were 238,590 and 29,720, respectively (1). Several studies have been performed and their results suggested that the etiology of prostate cancer was extremely complicated, and may be associated with several factors, including smoking, environment, dietary habits, endocrine system, age and ethnicity (2-7). However, the accurate etiology and pathogenesis remain inconsistent. Recently, a number of studies suggested that inflammation and genetic factors may play an important role in the etiology of prostate cancer (8-14). The prostaglandin-endoperoxide synthase 2 gene that encodes the cyclooxygenase- 2 enzyme has been verified to play an important role in the development of prostate cancer in numerous studies (15-18). The study by Woo et al (19) observed that tumor infiltrating B-cells were increased in prostate cancer tissue. The Lv et al (20) study suggested that hypoxia promoted the invasiveness of prostate cancer PC3 cells via hypoxia-inducible factor- $1 \alpha$ - and tumor necrosis factor- $\alpha$-induced stabilization of Snail. McDonald et al (21) investigated the associations between systemic inflammatory markers and serum prostate-specific antigen (PSA) in 3,164 healthy males and found that elevated serum PSA (194 males, $6.1 \%$ of the total) was significantly associated with plasma fibrinogen, suggesting that the markers of systemic inflammation were associated with elevated PSA in males without a known prostate disease.

Among the cytokines involved in inflammation, interleukin-6 (IL-6) plays a key role in the inflammation process. IL-6 is one of the most potent proinflammatory cytokines during acute inflammation, inducing and regulating the production of acute phase proteins (22). Previously, several studies have shown that the IL-6 polymorphism is significantly associated with a number of diseases and plays an important role in the etiology of diseases (23-29). With regards to prostate cancer, the Mandić et al (30) study indicated that the IL-6 -174 single-nucleotide polymorphism (SNP) distribution may vary between ethnicities and that a single cytokine-gene 
polymorphism probably has only a minor influence on prostate cancer susceptibility. The study by Pierce et al (31) suggested that circulating IL-6 and its gene polymorphism did not influence the prostate cancer risk, whereas Mandal et al (32) had an opposing opinion. Due to these conflicting results, the present meta-analysis was conducted to provide a comprehensive assessment of the associations of the IL-6 (-174 G/C) gene polymorphism with the risk of prostate cancer.

\section{Materials and methods}

Search strategy. Databases, including PubMed, Embase, Web of Science, the Cochrane Library, Chinese Biomedical Literature Database and Wanfang database, were searched between January 1994 and March 2014 for all the possible studies using an analytical design (including case-control and cohort studies) that mainly studied the association between the IL-6 (-174 G/C) gene polymorphism and the susceptibility of prostate cancer. The search terms used included: 'Prostate cancer' or 'PCa;' 'interleukin 6' or 'IL-6;' and 'polymorphism,' 'single-nucleotide polymorphism,' 'SNP' or 'variation;' and there was no language restriction in the literature search. To find more eligible studies that may not have been included in the initial search, the references of the candidate studies were examined and searches of unpublished literature were conducted.

Inclusion and exclusion criteria. The studies in the meta-analysis were included according to the following criteria: i) Analytical design (including case-control and cohort studies); ii) evaluation of the prostate cancer risk and IL-6 (-174 G/C) gene polymorphism; iii) sufficient data, including the number or frequency of alleles and genotypes; and iv) genotype frequencies in control groups should be abided by the Hardy-Weinberg equilibrium (HWE). The exclusion criteria included: i) Case studies and reviews; ii) no sufficient data reported; and iii) duplicated studies.

Data extraction. The quantitative data of all the eligible studies were extracted according to the inclusion and exclusion criteria by two investigators independently and a consensus was attempted if the data for one investigator was inconsistent with the other. The following characteristics of each study were collected: Authors, year of publication, study design, ethnicity, group, sample size, alleles and IL-6 genotypes. Certain studies included more than one ethnicity, therefore the information data were extracted separately according to the ethnicity.

Data synthesis and statistical analysis. The pooled odds ratio (OR) with $95 \%$ confidence interval $(95 \% \mathrm{CI})$ was calculated to assess the associations between the IL-6 (-174 G/C) gene polymorphism and prostate cancer according to allele contrast (C vs. G), homozygote (CC vs. GG), heterozygote (GC vs. GG), dominant (GC/CC vs. GG) and recessive (CC vs. GC/GG) models, and $\mathrm{P}<0.05$ was considered to indicate a statistically significant difference. The subgroup analysis was also performed to determine whether there was a significant association between the IL-6 (-174 G/C) gene polymorphism and prostate cancer in different ethnicities. The heterogeneity assumption was checked by a $\chi^{2}$-based $Q$ statistic test and

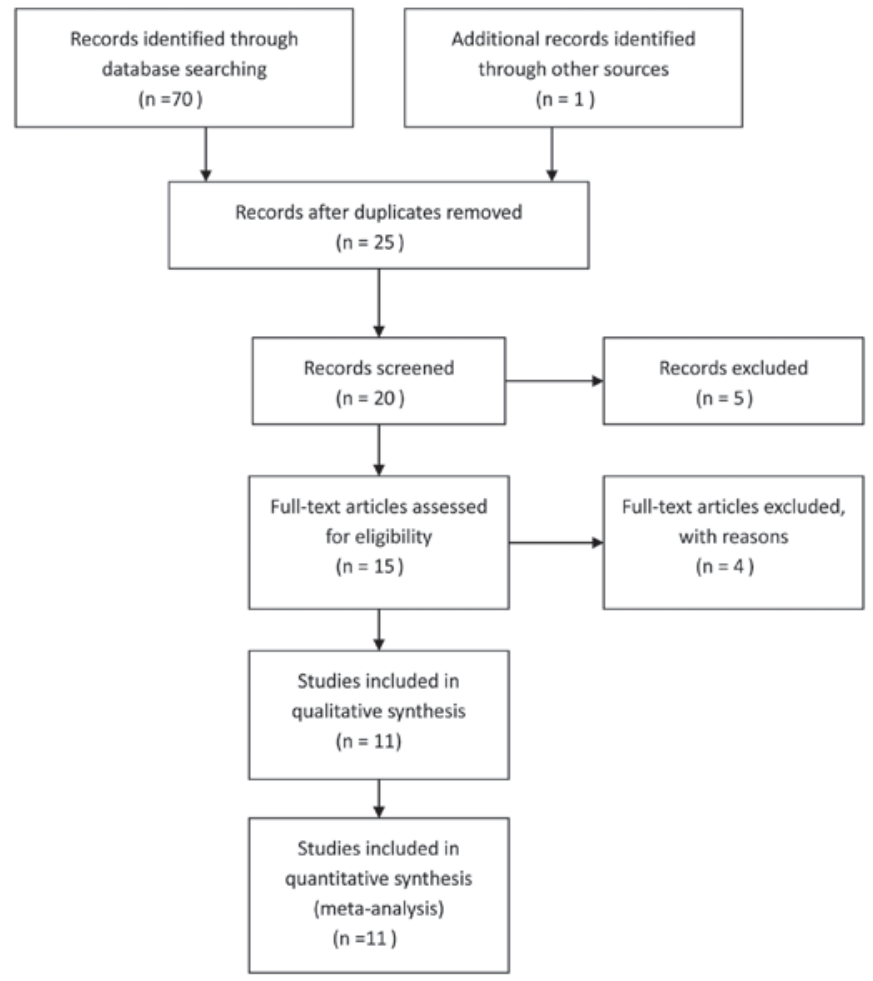

Figure 1. Study selection and inclusion process.

quantified by the $\mathrm{I}^{2}$ metric value. When $\mathrm{I}^{2}>50 \%$ or $\mathrm{P}<0.10$, suggesting that a clear heterogeneity existed, the ORs were pooled by the random-effect model, but for other cases the fixed-effect model was used. In addition, the sensitivity analysis was performed by individually removing the included studies to assess the impact of each study on the combined effect of the present meta-analysis. Stata 12.0 software (StataCorp, College Station, TX, USA) was used to analyze the data in the study.

\section{Results}

Study characteristics. In the initial search, the total studies were identified and 11 studies (30-40) with 10,745 cases and 13,473 controls eventually satisfied the eligibility criteria (Fig. 1). Among these studies, 10 (30,32-40) were case-control studies and only one (31) was a cohort study. Three studies $(31,32,40)$ were conducted in Caucasian and African-American patients; five $(30,34-36,39)$ reported the results in Caucasian patients only, two studied Asian patients $(37,38)$ and one (33) was conducted in a mixed population (Caucasian and African-American). Additionally, 10 studies (31-40) reported the alleles and genotypes of IL-6 $(-174 \mathrm{G} / \mathrm{C})$ and one (30) reported only the number of $\mathrm{CC}$ and $\mathrm{GG}+\mathrm{GC}$ genotypes. The general demographical characteristics of the studies included in the meta-analysis are summarized in Table I. The genotype distributions in the controls of all the studies were consistent with HWE.

Meta-analysis results. In the meta-analysis, there were no associations found between the IL-6 (-174 G/C) polymorphism and prostate cancer susceptibility in the overall population in all the genetic models indicated in Table II (allele contrast: 
Table I. General characteristics of the studies included in the meta-analysis.

\begin{tabular}{|c|c|c|c|c|c|c|c|c|c|c|c|}
\hline \multirow[b]{2}{*}{ Author } & \multirow[b]{2}{*}{ Year } & \multirow[b]{2}{*}{ Study design } & \multirow[b]{2}{*}{ Ethnicity } & \multirow[b]{2}{*}{ Group } & \multirow[b]{2}{*}{ Size } & \multicolumn{2}{|c|}{ IL-6 alleles } & \multicolumn{3}{|c|}{ IL-6 genotypes } & \multirow[b]{2}{*}{ (Refs.) } \\
\hline & & & & & & G & $\mathrm{C}$ & GG & GC & $\mathrm{CC}$ & \\
\hline $\begin{array}{l}\text { Mandal } \\
\text { et al }\end{array}$ & 2014 & Case-control & $\begin{array}{l}\text { African- } \\
\text { American }\end{array}$ & $\begin{array}{l}\text { Case } \\
\text { Control } \\
\text { Case } \\
\text { Control }\end{array}$ & $\begin{array}{l}84 \\
78 \\
80 \\
62\end{array}$ & $\begin{array}{r}128 \\
82 \\
132 \\
110\end{array}$ & $\begin{array}{l}40 \\
74 \\
28 \\
14\end{array}$ & $\begin{array}{l}50 \\
26 \\
58 \\
48\end{array}$ & $\begin{array}{l}28 \\
30 \\
16 \\
14\end{array}$ & $\begin{array}{r}6 \\
22 \\
6 \\
0\end{array}$ & (32) \\
\hline $\begin{array}{l}\text { Mandic } \\
\text { et al }\end{array}$ & 2013 & Case-control & Caucasian & $\begin{array}{l}\text { Case } \\
\text { Control }\end{array}$ & $\begin{array}{l}120 \\
120\end{array}$ & - & - & $\begin{array}{r}97^{\mathrm{a}} \\
104^{\mathrm{a}}\end{array}$ & $\begin{array}{l}- \\
-\end{array}$ & $\begin{array}{l}23 \\
16\end{array}$ & $(30)$ \\
\hline $\begin{array}{l}\text { Zhang } \\
\text { et al }\end{array}$ & 2010 & Case-control & $\begin{array}{l}\text { Mixed } \\
\text { population }\end{array}$ & $\begin{array}{l}\text { Case } \\
\text { Control }\end{array}$ & $\begin{array}{l}193 \\
197\end{array}$ & $\begin{array}{l}246 \\
275\end{array}$ & $\begin{array}{l}140 \\
119\end{array}$ & $\begin{array}{r}80 \\
100\end{array}$ & $\begin{array}{l}86 \\
75\end{array}$ & $\begin{array}{l}27 \\
22\end{array}$ & (33) \\
\hline $\begin{array}{l}\text { Dossus } \\
\text { et al }\end{array}$ & 2010 & Case-control & Caucasian & $\begin{array}{l}\text { Case } \\
\text { Control }\end{array}$ & $\begin{array}{l}7939 \\
8508\end{array}$ & $\begin{array}{l}10406 \\
11066\end{array}$ & $\begin{array}{l}5468 \\
5950\end{array}$ & $\begin{array}{l}3594 \\
3832\end{array}$ & $\begin{array}{l}3218 \\
3402\end{array}$ & $\begin{array}{l}1125 \\
1274\end{array}$ & (34) \\
\hline $\begin{array}{l}\text { Zabaleta } \\
\text { et al }\end{array}$ & 2009 & Case-control & $\begin{array}{l}\text { Caucasian } \\
\text { African- } \\
\text { American }\end{array}$ & $\begin{array}{l}\text { Case } \\
\text { Control } \\
\text { Case } \\
\text { Control }\end{array}$ & $\begin{array}{r}74 \\
401 \\
15 \\
57\end{array}$ & $\begin{array}{r}72 \\
415 \\
22 \\
92\end{array}$ & $\begin{array}{r}76 \\
387 \\
8 \\
22\end{array}$ & $\begin{array}{r}19 \\
126 \\
10 \\
41\end{array}$ & $\begin{array}{r}34 \\
163 \\
2 \\
10\end{array}$ & $\begin{array}{r}21 \\
112 \\
3 \\
6\end{array}$ & (40) \\
\hline Wang et al & 2009 & Case-control & Caucasian & $\begin{array}{l}\text { Case } \\
\text { Control }\end{array}$ & $\begin{array}{l}250 \\
252\end{array}$ & $\begin{array}{l}298 \\
296\end{array}$ & $\begin{array}{l}202 \\
208\end{array}$ & $\begin{array}{l}91 \\
84\end{array}$ & $\begin{array}{l}116 \\
128\end{array}$ & $\begin{array}{l}43 \\
40\end{array}$ & (35) \\
\hline $\begin{array}{l}\text { Moore } \\
\text { et al }\end{array}$ & 2009 & Case-control & Caucasian & $\begin{array}{l}\text { Case } \\
\text { Control }\end{array}$ & $\begin{array}{l}957 \\
847\end{array}$ & $\begin{array}{l}867 \\
793\end{array}$ & $\begin{array}{r}1047 \\
901\end{array}$ & $\begin{array}{l}191 \\
196\end{array}$ & $\begin{array}{l}485 \\
401\end{array}$ & $\begin{array}{l}281 \\
250\end{array}$ & (36) \\
\hline $\begin{array}{l}\text { Pierce } \\
\text { et al }\end{array}$ & 2009 & Cohort study & $\begin{array}{l}\text { Caucasian } \\
\text { African- } \\
\text { American }\end{array}$ & $\begin{array}{l}\text { Case } \\
\text { Control } \\
\text { Case } \\
\text { Control }\end{array}$ & $\begin{array}{r}175 \\
1758 \\
40 \\
260\end{array}$ & $\begin{array}{r}192 \\
2101 \\
73 \\
475\end{array}$ & $\begin{array}{r}158 \\
1415 \\
7 \\
45\end{array}$ & $\begin{array}{r}48 \\
648 \\
34 \\
216\end{array}$ & $\begin{array}{r}96 \\
805 \\
5 \\
43\end{array}$ & $\begin{array}{r}31 \\
305 \\
1 \\
1\end{array}$ & (31) \\
\hline Bao et al & 2008 & Case-control & Asian & $\begin{array}{l}\text { Case } \\
\text { Control }\end{array}$ & $\begin{array}{l}136 \\
120\end{array}$ & $\begin{array}{l}272 \\
240\end{array}$ & $\begin{array}{l}0 \\
0\end{array}$ & $\begin{array}{l}136 \\
120\end{array}$ & $\begin{array}{l}0 \\
0\end{array}$ & $\begin{array}{l}0 \\
0\end{array}$ & (37) \\
\hline $\begin{array}{l}\text { Kesarwani } \\
\text { et al }\end{array}$ & 2008 & Case-control & Asian & $\begin{array}{l}\text { Case } \\
\text { Control }\end{array}$ & $\begin{array}{l}200 \\
200\end{array}$ & $\begin{array}{l}288 \\
293\end{array}$ & $\begin{array}{l}112 \\
107\end{array}$ & $\begin{array}{l}102 \\
103\end{array}$ & $\begin{array}{l}84 \\
87\end{array}$ & $\begin{array}{l}14 \\
10\end{array}$ & $(38)$ \\
\hline $\begin{array}{l}\text { Michaud } \\
\text { et al }\end{array}$ & 2006 & Case-control & Caucasian & $\begin{array}{l}\text { Case } \\
\text { Control }\end{array}$ & $\begin{array}{l}484 \\
613\end{array}$ & $\begin{array}{l}563 \\
753\end{array}$ & $\begin{array}{l}405 \\
473\end{array}$ & $\begin{array}{l}170 \\
230\end{array}$ & $\begin{array}{l}223 \\
293\end{array}$ & $\begin{array}{l}91 \\
90\end{array}$ & (39) \\
\hline
\end{tabular}

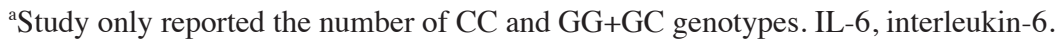

C vs. G; heterozygote model: GC vs. GG; and homozygote model: CC vs. GG), Fig. 2 (dominant model: GC/CC vs. GG) and Fig. 3 (recessive model: CC vs. GG/GC). The subgroup analysis suggested that the IL-6 (-174 G/C) polymorphism was not significantly associated with prostate cancer in Asian, Caucasian and mixed population patients under the allele contrast, homozygote, heterozygote, dominant and recessive models. However, in African-American patients, the subgroup analysis suggested that there was a slightly significant association between the IL-6 (-174 G/C) polymorphism and prostate cancer risk in the homozygote and recessive models (CC vs. GG: OR, 3.43; 95\% CI, 1.01-11.71; $\mathrm{P}=0.049$; CC vs. GG/GC: OR, 3.51; 95\% CI, 1.04-11.82; $\mathrm{P}=0.042$, respectively) (Figs. 3 and 4 ) and no significant association was found in the allele contrast, heterozygote and dominant models (Table II and Fig. 2).

Sensitivity analysis. To evaluate the stability of the meta-analysis, a leave-one-out sensitivity analysis was performed. The sensitivity analysis suggested that the independent study by Mandal et al (32) influenced the interpretation of the results in the homozygote and recessive models for African-American patients. When the Mandal et al (32) study was removed from the present meta-analysis, no significant association was found between the IL-6 (-174 G/C) polymorphism and the risk of prostate cancer in African-American patients under the homozygote $(\mathrm{OR}, 2.67 ; 95 \% \mathrm{CI}, 0.69-10.36 ; \mathrm{P}=0.17)$ and recessive models (OR, 2.64; 95\% CI, 0.70-9.98; P=0.15). However, no single study influenced the results in the overall population by the sensitivity analysis.

Publication bias. The Begg's test was performed and the results did not reveal any evidence of clear asymmetry (C vs. $\mathrm{G}, \mathrm{P}=0.95$; $\mathrm{CC}$ vs. $\mathrm{GG}, \mathrm{P}=0.73$; $\mathrm{GC}$ vs. $\mathrm{GG}, \mathrm{P}=0.54$; $\mathrm{GC} / \mathrm{CC}$ vs. $\mathrm{GG}, \mathrm{P}=0.63$; and $\mathrm{CC}$ vs. $\mathrm{GC} / \mathrm{GG}, \mathrm{P}=0.06$ ), suggesting the absence of publication bias in the meta-analysis.

\section{Discussion}

Prostate cancer is a common cause of cancer mortality in males and it is widely considered that age, diet, ethnicity and environmental factors contribute to the prostate cancer 
Table II. Results of the allele contrast, heterozygote and homozygote models for the IL-6 (-174 G/C) polymorphism and the risk of prostate cancer.

\begin{tabular}{|c|c|c|c|c|c|}
\hline \multirow[b]{2}{*}{ Comparison } & \multicolumn{2}{|c|}{ Association test } & \multicolumn{3}{|c|}{ Heterogeneity test } \\
\hline & OR & $95 \%$ CI & P-value & $\mathrm{P}$ & $\mathrm{I}^{2}(\%)$ \\
\hline \multicolumn{6}{|l|}{ Overall } \\
\hline C vs. G & 1.05 & $0.93-1.28$ & 0.43 & 0.00 & 67.00 \\
\hline GC vs. GG & 1.03 & $0.97-1.10$ & 0.28 & 0.08 & 38.70 \\
\hline CC vs. GG & 1.13 & $0.89-1.43$ & 0.32 & 0.002 & 62.70 \\
\hline \multicolumn{6}{|l|}{ Ethnicity } \\
\hline \multicolumn{6}{|l|}{ Caucasian } \\
\hline C vs. G & 1.00 & $0.87-1.15$ & 0.98 & 0.00 & 77.80 \\
\hline GC vs. GG & 1.03 & 0.97-1.09 & 0.34 & 0.02 & 60.10 \\
\hline CC vs. GG & 1.03 & $0.79-1.33$ & 0.83 & 0.001 & 72.60 \\
\hline \multicolumn{6}{|c|}{ African-American } \\
\hline C vs. G & 1.40 & $0.88-2.22$ & 0.16 & 0.65 & 0.00 \\
\hline GC vs. GG & 0.85 & $0.47-1.52$ & 0.58 & 0.93 & 0.00 \\
\hline $\mathrm{CC}$ vs. GG & 3.43 & $1.01-11.71$ & $0.049^{\mathrm{a}}$ & 0.53 & 0.00 \\
\hline \multicolumn{6}{|l|}{ Asian } \\
\hline C vs. G & 1.06 & $0.78-1.45$ & 0.69 & 1.00 & 0.00 \\
\hline GC vs. GG & 0.97 & $0.65-1.46$ & 0.90 & 1.00 & 0.00 \\
\hline CC vs. GG & 1.41 & $0.60-3.33$ & 0.43 & 1.00 & 0.00 \\
\hline \multicolumn{6}{|c|}{ Mixed population } \\
\hline C vs. G & 1.32 & $0.98-1.77$ & 0.07 & 1.00 & 0.00 \\
\hline GC vs. GG & 1.43 & $0.94-2.20$ & 0.10 & 1.00 & 0.00 \\
\hline CC vs. GG & 1.53 & $0.81-2.90$ & 0.19 & 1.00 & 0.00 \\
\hline
\end{tabular}

${ }^{\mathrm{a}} \mathrm{P} \leq 0.05$. IL-6, interleukin-6; OR, odds ratio; 95\% CI, 95\% confidence interval.

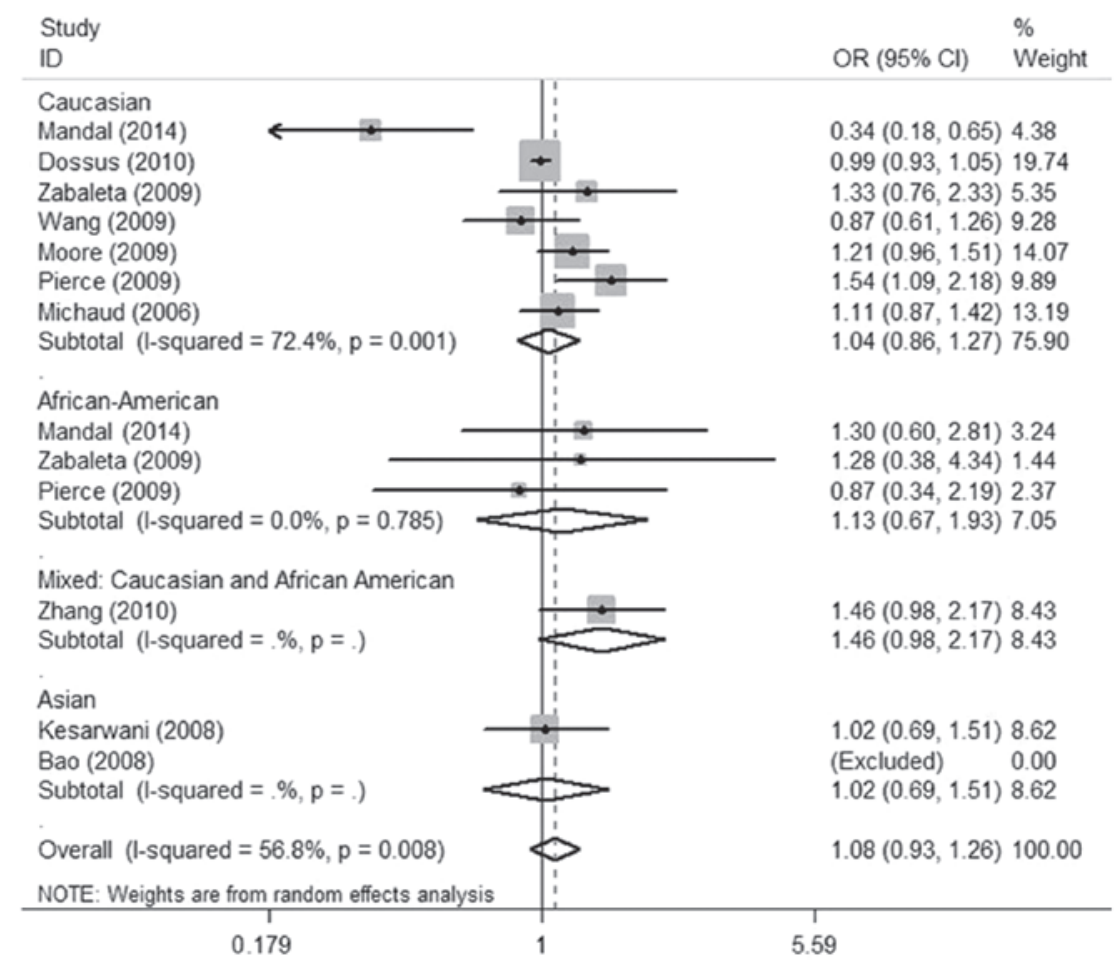

Figure 2. Forest plot describing the meta-analysis under the dominant model for the association between the interleukin-6 (-174 G/C) polymorphism and the risk of prostate cancer (GC/CC vs. GG). OR, odds ratio; 95\% CI, 95\% confidence interval. 


\begin{tabular}{|c|c|c|}
\hline $\begin{array}{l}\text { Study } \\
\text { ID }\end{array}$ & OR $(95 \% \mathrm{Cl})$ & $\begin{array}{l}\% \\
\text { Weight }\end{array}$ \\
\hline \multicolumn{3}{|l|}{ Caucasian } \\
\hline Mandic (2013) & $1.54(0.77,3.09)$ & 5.11 \\
\hline Mandal (2014) & $0.20(0.07,0.51)$ & 2.97 \\
\hline Dossus (2010) & $0.94(0.86,1.02)$ & 22.01 \\
\hline Zabaleta (2009) & $1.02(0.59,1.77)$ & 7.22 \\
\hline Wang (2009) & $1.10(0.69,1.76)$ & 8.84 \\
\hline Moore (2009) & $0.99(0.81,1.22)$ & 17.84 \\
\hline Pierce (2009) & $1.03(0.68,1.54)$ & 10.49 \\
\hline Michaud (2006) & $1.35(0.98,1.85)$ & 13.29 \\
\hline Subtotal $(l-s q u a r e d=59.5 \%, p=0.016)$ & $1.01(0.84,1.22)$ & 87.78 \\
\hline \multicolumn{3}{|l|}{ African-American } \\
\hline Mandal (2014) & $10.91(0.60,197.42)$ & 0.37 \\
\hline Zabaleta (2009) & $2.13(0.46,9.73)$ & 1.29 \\
\hline Pierce (2009) & $6.64(0.41,108.36)$ & 0.40 \\
\hline Subtotal $(1-$ squared $=0.0 \%, p=0.526)$ & $3.51(1.04,11.82)$ & 2.07 \\
\hline \multicolumn{3}{|l|}{ Mixed: Caucasian and African American } \\
\hline Zhang (2010) & $1.29(0.71,2.36)$ & 6.36 \\
\hline Subtotal $(1-$ squared $=. \%, p=)$. & $1.29(0.71,2.36)$ & 6.36 \\
\hline \multicolumn{3}{|l|}{ Asian } \\
\hline Kesarwani (2008) & $1.43(0.62,3.30)$ & 3.79 \\
\hline Bao (2008) & (Excluded) & 0.00 \\
\hline Subtotal $(1-$ squared $=. \%, p=)$. & $1.43(0.62,3.30)$ & 3.79 \\
\hline Overall $(\mathrm{l}$-squared $=51.0 \%, p=0.018)$ & $1.07(0.89,1.28)$ & 100.00 \\
\hline \multicolumn{3}{|l|}{ NOTE: Weights are from random effects analysis } \\
\hline 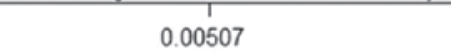 & & \\
\hline
\end{tabular}

Figure 3. Forest plot describing the meta-analysis under the recessive model for the association between the interleukin-6 (-174 G/C) polymorphism and the risk of prostate cancer (CC vs. GG/GC). OR, odds ratio; 95\% CI, 95\% confidence interval.

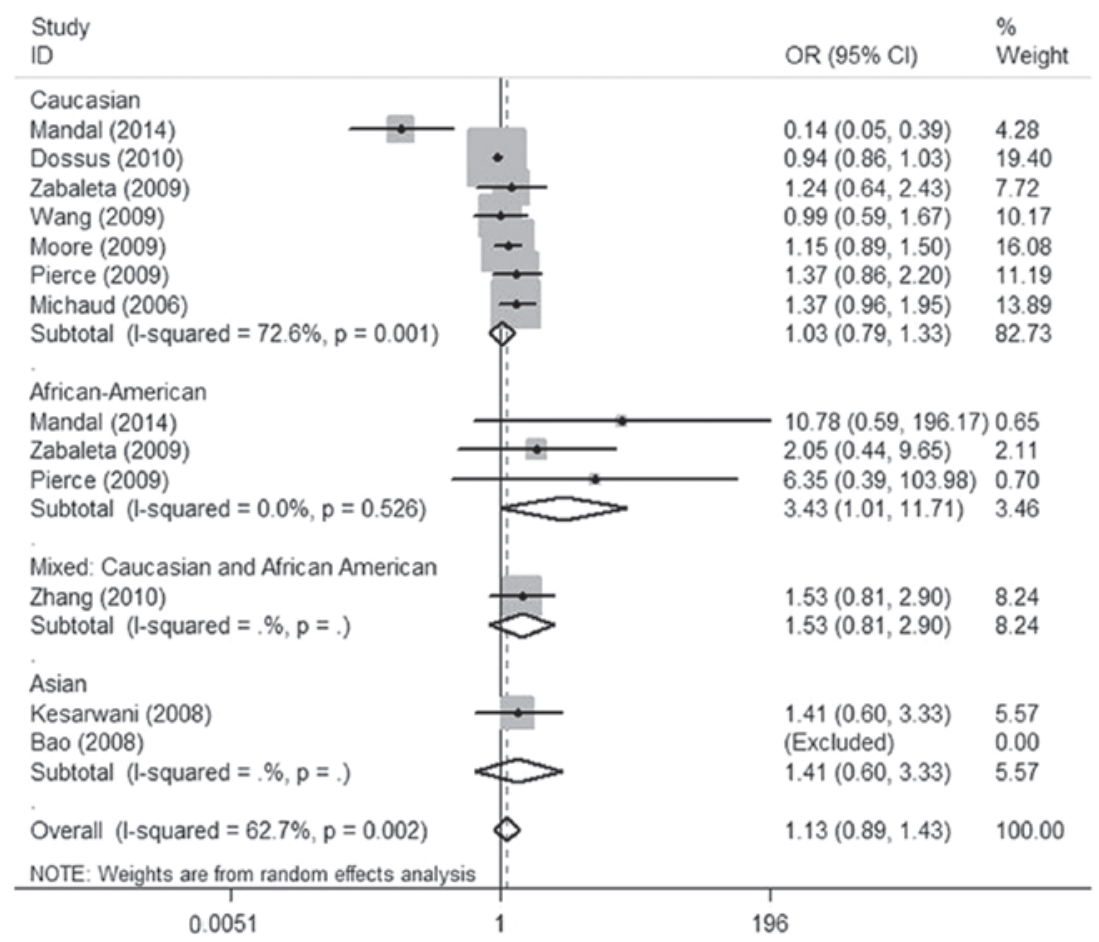

Figure 4. Forest plot describing the meta-analysis under the homozygote model for the association between the interleukin-6 (-174 G/C) polymorphism and the risk of prostate cancer (CC vs. GG). OR, odds ratio; 95\% CI, 95\% confidence interval.

etiology (2,5-7), but recently the genetic background and inflammation are considered as sensitive factors for the differences in prostate cancer susceptibility $(37,40)$. Following the identification of the IL-6 (-174 G/C) polymorphism, attention to determine whether the IL-6 (-174 G/C) polymorphism is associated with prostate cancer, not only in the overall population but also in different ethnicities, has increased. Bao et al (37) used TaqMan polymerase chain reaction to gene-type the IL-6 (-174 G/C) polymorphism for comparing the prostate cases and controls in terms of allele frequency, 
genotype frequency and risk of prostate cancer. The results suggested that no significant association was found in the population of Han people in the Hubei region, which was also identified in Caucasian patients (36). Additionally, two meta-analyses $(41,42)$ based on studies published 4-10 years ago also held the same conclusion. However, a recent study published in January 2014 by Mandal et al (32) suggested that the GG genotype may be associated with an increased risk of prostate cancer in Caucasian subjects, whereas the $\mathrm{CC}$ genotype was associated with an increased risk in the African-American subjects.

In order to determine whether the IL-6 (-174 G/C) polymorphism is associated with the prostate cancer risk in the overall population and different ethnic populations, the present meta-analysis of 11 independent studies was performed, which included 10,745 cases and 13,473 controls based on several recently published studies, whose results were inconsistent with former studies. In the meta-analysis, it was found that the IL-6 (-174 G/C) polymorphism is not a risk factor for prostate cancer in the overall population. However, the present study suggested that there was a slightly significant association between the IL-6 (-174 G/C) polymorphism and prostate risk in African-American patients under the homozygote and recessive models (CC vs. GG: OR, 3.43; 95\% CI, 1.01-11.71; $\mathrm{P}=0.049$; and $\mathrm{CC}$ vs. GG/GC: OR, 3.51; 95\% CI, 1.04-11.82; $\mathrm{P}=0.042$, respectively), which contradicts the results of the Magalhaes et al (41) meta-analysis. In addition, no significant associations were found in Asians and Caucasians, which is consistent with the Magalhaes et al (41) and Zhang et al (42) studies, suggesting that ancestral genetic factors in different populations may have an impact on prostate cancer susceptibility. Additionally, the removal of the Mandal et al (32) study from the present meta-analysis showed that no significant association was found between the IL-6 (-174 G/C) polymorphism and the risk of prostate cancer in African-American patients under the homozygote (OR, 2.67; 95\% CI, 0.69-10.36; $\mathrm{P}=0.17$ ) and recessive models (OR, 2.64; 95\% CI, 0.70-9.98; $\mathrm{P}=0.15$ ). The potential explanation for this may involve the different patients recruited in each independent study, as well as their different lifestyles, different experimental procedures and complex gene-gene and gene-environment interaction, which may also have contributed to these conflicting results.

Although the comprehensive analysis was conducted to show the association between the IL- $6(-174 \mathrm{G} / \mathrm{C})$ gene polymorphism and prostate cancer risk, there are particular limitations that should be identified. Firstly, for the African-American patients, only three studies were conducted and the results of these studies were contradictory. Therefore, it may be difficult to explore the real association in African-American patients. Secondly, only two studies that were conducted in Asian patients fulfilled the inclusion criteria, which could not provide enough statistical power to detect the possible effects of the IL-6 (-174 G/C) gene polymorphism on prostate cancer in Asian patients. Thirdly, the studies included in the meta-analysis were conducted in Caucasian, Asian and African-American patients, which may not represent the negative associations in all the worldwide ethnicities. In addition, the possibility of gene-gene interactions or environmental factors or the possibility of linkage disequilibrium between the polymorphisms were also not considered in the study.
Therefore, larger-scale and well-designed studies are necessary to estimate the association between the IL-6 (-174 G/C) polymorphism and the risk of prostate cancer.

In conclusion, although there were certain limitations in the meta-analysis, the study was based on a substantial number of cases and controls and suggested that there was no significant association between IL-6 (-174 G/C) polymorphism and the prostate cancer risk in the overall population, as well as in Caucasian and Asian patients, whereas the CC genotype may be associated with an increased prostate cancer risk in the African-American patients. Due to these limitations, more studies that consider lifestyle, complex gene-gene and gene-environment interactions or family history should be conducted to further assess the associations of the IL-6 $(-174 \mathrm{G} / \mathrm{C})$ gene polymorphisms with the risk of prostate cancer.

\section{References}

1. Siegel R, Naishadham D and Jemal A: Cancer statistics, 2013. CA Cancer J Clin 63: 11-30, 2013.

2. Discacciati A and Wolk A: Lifestyle and dietary factors in prostate cancer prevention. Recent Results Cancer Res 202: 27-37, 2014

3. Lai GY, Giovannucci EL, Pollak MN, et al: Association of C-peptide and leptin with prostate cancer incidence in the Health Professionals Follow-up Study. Cancer Causes Control 25: 625-632, 2014.

4. Wu J and Yu E: Insulin-like growth factor receptor-1 (IGF-IR) as a target for prostate cancer therapy. Cancer Metastasis Rev: Jan 12,2014 (Epub ahead of print).

5. McGregor SE, Courneya KS, Kopciuk KA, Tosevski C and Friedenreich CM: Case-control study of lifetime alcohol intake and prostate cancer risk. Cancer Causes Control 24: 451-461, 2013.

6. Rundle A, Jankowski M, Kryvenko ON, Tang D and Rybicki BA: Obesity and future prostate cancer risk among men after an initial benign biopsy of the prostate. Cancer Epidemiol Biomarkers Prev 22: 898-904, 2013.

7. Nelson WG, Demarzo AM and Yegnasubramanian S: The diet as a cause of human prostate cancer. Cancer Treat Res 159: 51-68, 2014.

8. Sfanos KS, Isaacs WB and DeMarzo AM: Infections and inflammation in prostate cancer. Am J Clin Exp Urol 1: 3-11, 2013.

9. Kwon OJ, Zhang L, Ittmann MM and Xin L: Prostatic inflammation enhances basal-to-luminal differentiation and accelerates initiation of prostate cancer with a basal cell origin. Proc Natl Acad Sci USA 111: E592-E600, 2014.

10. Boikos SA, Nirschl C, Martin A, Alme A, Harris T and Drake CG: Prostate cancer cells up-regulate PD-L1 in response to pro-inflammatory cytokines. Cancer Res 73 (Suppl 1): Abstract 1437, 2013.

11. Ianni M, Porcellini E, Carbone I, et al: Genetic factors regulating inflammation and DNA methylation associated with prostate cancer. Prostate Cancer Prostatic Dis 16: 56-61, 2013.

12. Miyake M, Lawton A, Goodison S, Urquidi V and Rosser CJ: Chemokine (C-X-C motif) ligand 1 (CXCL1) protein expression is increased in high-grade prostate cancer. Pathol Res Pract 210: 74-78, 2014.

13. Dakhova O, Rowley D and Ittmann M: Genes upregulated in prostate cancer reactive stroma promote prostate cancer progression in vivo. Clin Cancer Res 20: 100-109, 2014.

14. Heber D: Cancer and inflammation. In: Immunonutrition: Interactions of Diet, Genetics, and Inflammation. Aggarwal BB and Heber D (eds). CRC Press, Boca Raton, FL, 101, 2014.

15. Cheng I, Liu X, Plummer SJ, Krumroy LM, Casey G and Witte JS: COX2 genetic variation, NSAIDs, and advanced prostate cancer risk. Br J Cancer 97: 557-561, 2007.

16. Danforth KN, Hayes RB, Rodriguez C, et al: Polymorphic variants in PTGS2 and prostate cancer risk: results from two large nested case-control studies. Carcinogenesis 29: 568-572, 2008 . 
17. Shahedi K, Lindström S, Zheng SL, et al: Genetic variation in the COX-2 gene and the association with prostate cancer risk. Int J Cancer 119: 668-672, 2006.

18. Panguluri RC, Long LO, Chen $\mathrm{W}$, et al: COX-2 gene promoter haplotypes and prostate cancer risk. Carcinogenesis 25: 961-966, 2004.

19. Woo JR, Liss MA, Muldong MT, et al: Tumor infiltrating B-cells are increased in prostate cancer tissue. J Transl Med 12: 30, 2014

20. Lv L, Yuan J, Huang T, et al: Stabilization of Snail by HIF-1 $\alpha$ and TNF- $\alpha$ is required for hypoxia-induced invasion in prostate cancer PC3 cells. Mol Biol Rep: Mar 8, 2014 (Epub ahead of print).

21. McDonald AC, Vira MA, Vidal AC, Gan W, Freedland SJ and Taioli E: Association between systemic inflammatory markers and serum prostate-specific antigen in men without prostatic disease - the 2001-2008 National Health and Nutrition examination survey. Prostate 74: 561-567, 2014.

22. Lehrer S, Diamond EJ, Mamkine B, Droller MJ, Stone NN and Stock RG: C-reactive protein is significantly associated with prostate-specific antigen and metastatic disease in prostate cancer. BJU Int 95: 961-962, 2005.

23. Aulisa L, Papaleo P, Pola E, et al: Association between IL-6 and MMP-3 gene polymorphisms and adolescent idiopathic scoliosis: a case-control study. Spine (Phila Pa 1976) 32: 2700-2702, 2007.

24. Shibata N, Ohnuma T, Takahashi T, et al: Effect of IL-6 polymorphism on risk of Alzheimer disease: genotype-phenotype association study in Japanese cases. Am J Med Genet 114: 436-439, 2002

25. Bader H: Clinical and systemic implications of periodontal disease susceptibility: the importance of IL-6 polymorphism. Dentistry 4: 187, 2014

26. Yang Z, Liang Y, Qin B and Zhong R: A meta-analysis of the association of IL-6 $-174 \mathrm{G} / \mathrm{C}$ and $-572 \mathrm{G} / \mathrm{C}$ polymorphisms with systemic lupus erythematosus risk. Rheumatol Int 34: 199-205, 2014.

27. Zhang HY, Feng L, Wu H and Xie XD: The association of IL-6 and IL-6R gene polymorphisms with chronic periodontitis in a Chinese population. Oral Dis 20: 69-75, 2014.

28. Taniguchi K and Karin M: IL-6 and related cytokines as the critical lynchpins between inflammation and cancer. Semin Immunol 26: 54-74, 2014.

29. Yao X, Huang J, Zhong H, et al: Targeting interleukin-6 in inflammatory autoimmune diseases and cancers. Pharmacol Ther 141: 125-139, 2014.
30. Mandić S, Sudarević B, Marczi S, et al: Interleukin-6 polymorphism and prostate cancer risk in population of Eastern Croatia. Coll Antropol 37: 907-911, 2013.

31. Pierce BL, Biggs ML, DeCambre M, et al: C-reactive protein, interleukin-6, and prostate cancer risk in men aged 65 years and older. Cancer Causes Control 20: 1193-1203, 2009.

32. Mandal S, Abebe F and Chaudhary J: -174G/C polymorphism in the interleukin- 6 promoter is differently associated with prostate cancer incidence depending on race. Genet Mol Res 13: 139-151, 2014.

33. Zhang J, Dhakal IB, Lang NP and Kadlubar FF: Polymorphisms in inflammatory genes, plasma antioxidants, and prostate cancer risk. Cancer Causes Control 21: 1437-1444, 2010.

34. Dossus L, Kaaks R, Canzian F, et al: PTGS2 and IL6 genetic variation and risk of breast and prostate cancer: results from the Breast and Prostate Cancer Cohort Consortium (BPC3). Carcinogenesis 31: 455-461, 2010.

35. Wang MH, Helzlsouer KJ, Smith MW, et al: Association of IL10 and other immune response- and obesity-related genes with prostate cancer in CLUE II. Prostate 69: 874-885, 2009.

36. Moore SC, Leitzmann MF, Albanes D, et al: Adipokine genes and prostate cancer risk. Int J Cancer 124: 869-876, 2009.

37. Bao S, Yang W, Zhou S and Ye Z: Relationship between single nucleotide polymorphisms in $-174 \mathrm{G} / \mathrm{C}$ and $-634 \mathrm{C} / \mathrm{G}$ promoter region of interleukin-6 and prostate cancer. J Huazhong Univ Sci Technolog Med Sci 28: 693-696, 2008.

38. Kesarwani P, Ahirwar DK, Mandhani A and Mittal RD: Association between $-174 \mathrm{G} / \mathrm{C}$ promoter polymorphism of the interleukin-6 gene and progression of prostate cancer in North Indian population. DNA Cell Biol 27: 505-510, 2008.

39. Michaud DS, Daugherty SE, Berndt SI, et al: Genetic polymorphisms of interleukin-1B (IL-1B), IL-6, IL-8, and IL-10 and risk of prostate cancer. Cancer Res 66: 4525-4530, 2006

40. Zabaleta J, Su LJ, Lin HY, et al: Cytokine genetic polymorphisms and prostate cancer aggressiveness. Carcinogenesis 30 1358-1362, 2009.

41. Magalhães JF, Cortinhas AF, Albuquerque CM, et al: Interleukin- 6 gene $-174 \mathrm{G}>\mathrm{C}$ and $-636 \mathrm{G}>\mathrm{C}$ promoter polymorphisms and prostate cancer risk. Mol Biol Rep 40: 449-455, 2013.

42. Zhang H, Xu Y, Li L, Liu R and Ma B: The interleukin-6 -174G/C polymorphism and prostate cancer risk: a systematic review and meta-analysis. Urol Int 88: 447-453, 2012. 